\title{
miR-141-3p Suppresses Expression of Androgen Receptors and Functions as a Tumor Suppressor Gene in Prostate Carcinogenesis
}

\author{
Chunjiao Song1*, Huan Chen², Tingzhang Wang², Guomei Ru'1, Qiannan Ding1, Wanlei Yang1 \\ ${ }^{1}$ Medical Research Center, Shaoxing People's Hospital/Shaoxing Hospital of Zhejiang University, Shaoxing, China \\ ${ }^{2}$ Zhejiang Institute of Microbiology, Hangzhou, China \\ Email: *chunjiaosong@163.co
}

How to cite this paper: Song, C.J., Chen, H., Wang, T.Z., Ru, G.M., Ding, Q.N. and Yang, W.L. (2017) miR-141-3p Suppresses Expression of Androgen Receptors and Functions as a Tumor Suppressor Gene in Prostate Carcinogenesis. International Journal of Clinical Medicine, 8, 55-72.

https://doi.org/10.4236/ijcm.2017.82006

Received: February 1, 2017

Accepted: February 18, 2017

Published: February 21, 2017

Copyright $\odot 2017$ by authors and Scientific Research Publishing Inc. This work is licensed under the Creative Commons Attribution International License (CC BY 4.0).

http://creativecommons.org/licenses/by/4.0/

\section{(c) (i) Open Access}

\begin{abstract}
Background: Prostate cancer ( $\mathrm{PCa}$ ) is a leading cause of tumor mortality in Western societies. In China, the PCa mortality rate is increasing yearly. Androgen receptors (ARs) and microRNAs (miRNAs) play central roles in prostate carcinogenesis and progression. Methods: To characterize the underlying molecular mechanisms, we compared the miRNA profiles of early PCa (G $\leq$ 7), advanced PCa $(G>7)$ and non-tumor prostate tissues using deep-sequencing. The target genes of differentially expressed miRNAs were predicted by bioinformatics analysis and confirmed by luciferase reporter assays and Western blot (WB) and quantitative reverse transcription-PCR (qRT-PCR) analyses. Finally, we performed in vitro functional studies by inducing or inhibiting miR-141-3p expression using an artificial mimic or inhibitor. Results: A computational search implicated the open reading frame (ORF) of AR mRNA as a potential miR-141-3p target site. The qRT-PCR, WB and luciferase reporter assays revealed a reverse regulatory effect of miR-141-3p on AR. Mutation of the potential miR-141-3p binding site in the AR ORF resulted in a loss of responsiveness to the corresponding miRNA. Moreover, miR-141-3p expression levels were unchanged in early PCas, but were obviously increased in advanced PCas. MiR-141-3p overexpression inhibited RWPE-1 cell proliferation, mobility, and prohibited the entry of cells into the G2-S-M phase; miR-141-3p inhibition had the inverse effects. At the same time, we tested miR-141-3p's functions in PC-3 and VCaP prostate cancer cell lines. Conclusions: Taken together, our results indicate that miR-141-3p targets $A R$ and its downstream signaling pathways, and functions as a tumor suppressor miR in PCa carcinogenesis by suppressing cell growth and mobility, but the effect is not significant in maglinant PCas. MiR-141-3p is implicated as a novel therapeutic target for early PCa.
\end{abstract}




\section{Keywords}

Prostate Cancer, miR-141-3p, Androgen Receptor, Carcinogenesis

\section{Introduction}

Prostate cancer ( $\mathrm{PCa})$ is the most common malignancy of the male genitourinary tract, and the second leading cause of cancer deaths among males in Western societies [1]. In the United States in 2013, it was estimated that 238,590 new PCa cases were diagnosed with 29,720 attributable deaths [2]. Androgen receptors (ARs) are one of the most important nuclear transcription factors among the steroid hormone receptor superfamily of genes. Normal prostate growth and development, prostate carcinogenesis, and castration-resistant progression of $\mathrm{PCa}$ are dependent on AR expression and function. Alterations in AR structure, expression and signaling could have a defining role in PCa progression. AR is translocated to the nucleus in a dimerized form and regulates gene expression by binding to specific hormone response elements [3]. In the early stages, PCa depends on androgens for growth; therefore, the most effective systemic treatment for this hormone sensitive cancer is androgen deprivation therapy. However, the greatest problem associated with this approach is that, after hormone treatment, the tumor inevitably progresses from an androgen-dependent (AD) form to an incurable castration-resistant (CR) form. Many of these AR-regulated genes are key regulators of prostate development and maintenance. AR signaling is also critical to the initiation and progression of PCa.

MicroRNAs (miRNAs) are small regulatory RNAs that target mRNAs and cause mRNA cleavage and/or translational suppression. They may function as oncogenes or tumor suppressors. Aberrant miRNA expression is closely associated with growth, development, invasion, metastasis, and prognosis of various cancers, including PCa. A number of miRNAs have been reported to be upregulated or downregulated in human $\mathrm{PCa}$ and are used as biomarkers for diagnosis, prognosis, and classification. MiR-141-3p is one of these upregulated miRNAs in PCa cells and upregulation of miR-141-3p has been demonstrated to be a biomarker for the disease [4] [5] [6] [7] [8]. Nevertheless, the mechanism by which aberrant miR-141-3p expression contributes to prostate tumorigenesis is still not fully understood.

Several miRNA profiling studies in PCa have been reported, but the results regarding the deregulation of miRNAs are highly inconsistent. We have previously reported deregulation of miRNAs in PCa revealed by deep-sequencing in a study designed to investigate the expression levels and roles of miR-141-3p in PCa carcinogenesis [9]. Expression levels of objective genes were measured by deep-sequencing and quantitative polymerase chain reaction (qPCR) in a small cohort of patients with localized early PCa (Gleason $\leq 7$ ) and non-tumor control tissues [9]. In the present study, the expression levels of miR-141-3p and the ef- 
fects on AR transcriptional activity were estimated by upregulating or downregulating miR-141-3p using its mimic or inhibitor in the human non-malignant prostate epithelial cell line RWPE-1and human malignant prostate cancer cell lines PC-3 and VCaP. There were no differences in miR-141-3p expression in early PCa tissues compared to control benign prostatic hyperplasia (BPH) tissues. MiR-141-3p targeted the open reading frame (ORF) region of AR mRNA resulting in AR translational suppression and mRNA degradation and miR-141$3 p$ expression correlated inversely with AR expression. Moreover, in vitro functional studies performed by upregulating or downregulating miR-141-3p expression using an artificial mimic or inhibitor showed that miR-141-3p overexpression suppressed cell proliferation and attenuated mobility in RWPE-1 cells. Our findings not only provide new insights into the mechanisms of prostate tumorigenesis, but also reveal a novel strategy for early PCa therapy.

\section{Materials and Methods}

\subsection{Cell Culture}

The immortalized benign prostatic epithelial cell line RWPE-1 and human malignant prostate cancer cell lines PC-3 and VCaP, were obtained from the American Type Culture Collection (ATCC), and maintained in regular medium supplemented with $10 \%$ fetal bovine serum (FBS) at $37^{\circ} \mathrm{C}$ and under $5 \% \mathrm{CO}_{2}$ in a humidified incubator until $80 \%-90 \%$ confluence.

\subsection{Oligonucleotides and Cell Transfection}

MiR-141-3p mimic and inhibitor oligonucleotides (Biomics, Jiangsu China) were used at a $100 \mathrm{nM}$ final concentration in the experiments. RWPE-1 cells were plated in 12-well plates at $1.5-2.5 \times 10^{5}$ cells per well, grown for $24 \mathrm{~h}$ at $70 \%$ confluence, and then switched to antibiotic free media prior to transfection. Next, $5 \mu \mathrm{L}$ oligos and $4.8 \mu \mathrm{L}$ X-tremeGENE 9 DNA Transfection Reagent (Roche, Basel Switzerland) were added individually to $100 \mu \mathrm{L}$ Opti-MEM (Invitrogen, Carlsbad USA), and then incubated for at least $20 \mathrm{~min}$ before being added to the cultured cells. The overexpression and inhibition of miR-141-3p were achieved by transfection of commercial mature miRNA and antisense miRNA with an appropriate miRNA control. The cells were incubated with the aforementioned oligonucleotides after $48-72 \mathrm{~h}$. After transient transfection, total RNA extraction, genetic and functional characteristics were analyzed by qRT-PCR and WB.

\subsection{RNA Isolation and $q R T-P C R$ Analysis}

For quantitative expression analyses of mRNA and miRNA, total RNAs were isolated from Formalin-Fixed and Parrffin-Embedded (FFPE) prostatic tissues (Table S1 and Table S2) or cultured cells using Trizol reagent (Life Technologies, Carlsbad USA) according to the manufacturer's instructions. The RNA concentration and purity were measured with a Nanodrop 2000 (Thermo Scien- 
tific, Waltham USA). Total RNAs were reverse-transcribed by the M-MLV reverse transcriptase kit (Invitrogen), and residual DNA was removed by treatment with the DNA-free ${ }^{\mathrm{rm}}$ Kit (Ambion, Carlsbad USA). qRT-PCR was performed to detect AR mRNA and miR-141-3p levels using SYBR Green Premix DimerEraser (Takara, Japan) on a Roche 480 system. The primers used are listed in Table S3. Melting curves were determined following reactions using the following program: $30 \mathrm{~s}$ at $95^{\circ} \mathrm{C}$, followed by 40 cycles of $5 \mathrm{~s}$ at $95^{\circ} \mathrm{C}, 30 \mathrm{~s}$ at $56^{\circ} \mathrm{C}$, and $30 \mathrm{~s}$ at $72^{\circ} \mathrm{C}$, and the melting curve was determined. GAPDH (for mRNA) and U6 (for microRNAs) levels were used as internal controls, and fold changes were calculated by relative quantification $\left(2^{-\Delta \Delta C t}\right)$. To minimize experimental variation, tumor and control samples were analyzed on the same reaction plate, and all reactions were measured in triplicate.

\subsection{Western Blotting}

Transfected cells were lysed in radio-immunoprecipitation assay (RIPA) buffer (Thermo Scientific) supplemented with protease inhibitors $(100 \mathrm{mM}$ Tris- $\mathrm{HCl}$ at $\mathrm{pH}$ 7.4, $150 \mathrm{mM} \mathrm{NaCl}, 5 \mathrm{mM}$ EDTA, 1\% Triton X-100, 1\% deoxycholate acid, $0.1 \%$ SDS, $2 \mathrm{mM}$ phenylmethylsulfonyl fluoride, $1 \mathrm{mM}$ sodium orthovanadate, 2 $\mathrm{mM}$ DTT, $2 \mathrm{mM}$ leupeptin, and $2 \mathrm{mM}$ pepstatin). Lysates were centrifuged at $12,000 \mathrm{rpm}$ for $10 \mathrm{~min}$ under $4^{\circ} \mathrm{C}$, and supernatants containing total proteins were collected. Protein concentrations were determined by the BCA method (Beyotime, Jiangsu China), and aliquots of $20 \mu \mathrm{g}$ protein lysates were separated by SDS-polyacrylamide gel electrophoresis and then transferred to PVDF membranes (GE Healthcare Life Sciences, USA). Membranes were blocked with 5\% non-fat milk solution for $2 \mathrm{~h}$. Immunoblotting was performed using an antirabbit AR monoclonal antibody (diluted 1:1,000; Abcam, ER179(2)). GAPDH immunoblotting was performed using an anti-rabbit GAPDH antibody (Abcam, EPR6256). The secondary antibody was goat anti-rabbit HRP-linked (Abcam, ab6721), and blots were developed using enhanced chemiluminescence Detection System (Thermo Scientific). Protein levels were quantified using ImageJ $2 \times$ software and normalized to GAPDH levels.

\subsection{Luciferase Reporter Assays}

To construct reporter plasmids, a DNA fragment of the AR ORF containing the putative miR-141-3p binding site (5'-GCCATTGAGCCAGGTGTAGTGTG-3') was amplified by PCR from human CDNA. The AR ORF fragment lacking the miR-141-3p binding site (5'-GCCA-------AG-3') was used as negative control. DNA fragments were inserted downstream of the reporter gene of pmirGLO Dual-Luciferase miRNA Target Expression Vector (Promega) after SaII and $X b a I$ digestion. The sequences and cloning direction of these plasmids were validated by DNA sequencing. For luciferase reporter assay, 293T cells $\left(4 \times 10^{4}\right.$ per well) were seeded into 24 -well plates and cultured for $24 \mathrm{~h}$. The cells were then co-transfected with reporter plasmids and $100 \mathrm{nM}$ chemically synthesized miR141-3p mimic or miRNA negative control (miR-NC). After $48 \mathrm{~h}$, cells were har- 
vested and lysed with passive lysis buffer (Promega, Madison USA). Luciferase activity was measured using the Dual-Luciferase Reporter Assay System (Promega) on a Fluroskan Ascent FL Microplate Fluorometer (Thermo Electron) following the manufacturers' instructions. Luciferase activities were expressed as the ratio of firefly to Renilla luciferase activity and normalized to the levels detected in control transfections.

\subsection{Cell Proliferation Assay}

To assess the contribution of miR-141-3p to PCa cell proliferation, transiently transfected RWPE-1 cells were seeded into 96-well plates (3000 cells/well). Cells were incubated for $12 \mathrm{~h}$ to allow them to attach to the bottom of the well before the addition of 3-(4,5-dimethylthiazol-2-yl)-2,5-diphenyltetrazolium bromide (MTT, Sigma-Aldrich, St. Louis USA) to measure cell growth at different time points ( $1 \mathrm{~d}, 2 \mathrm{~d}, 3 \mathrm{~d}, 4 \mathrm{~d}, 5 \mathrm{~d}$ and $6 \mathrm{~d})$. According to the manufacturer's instructions, $10 \mu \mathrm{L}$ of MTT solution was added to the cultured cells, and incubated for 4 $\mathrm{h}$ at $37^{\circ} \mathrm{C}$. The supernatant was removed, and $200 \mu \mathrm{L}$ of DMSO was added to each well to solubilize the water-insoluble purple formazan crystals before the absorbance at $490 \mathrm{~nm}$ was measured. Experiments were performed in triplicate.

\subsection{Cell Cycle Assay}

Cells were plated in 12-well plates $\left(1.5-2.5 \times 10^{5}\right.$ cells/well $)$ and transfected with the miR-141-3p mimic or inhibitor. After $48-72 \mathrm{~h}$, cells were harvested by trypsinization, and $1 \times 10^{6}$ cells were used for cell cycle analysis. The cells were washed with PBS, fixed in $70 \%$ ice-cold ethanol overnight at $4^{\circ} \mathrm{C}$, then washed with PBS again and incubated with $1 \mathrm{~mL}$ staining solution $(20 \mu \mathrm{g} / \mathrm{mL}$ propidium iodide; $10 \mathrm{U} / \mathrm{mL}$ RNaseA) for $30 \mathrm{~min}$ at room temperature. The DNA content was measured by flow cytometry on a FACS Calibur system (Becton Dickinson, New Jersey USA), and cell cycle distributions of the different populations were determined using FlowJo software (Verity Software House).

\subsection{Wound-Healing Assay}

Transfected cells were cultured to $80 \%$ - 90\% confluence in 6-well plates. Cell layers were scratched using a $10 \mu \mathrm{L}$ pipette tip to form wound gaps and then washed twice with PBS. The wound-healing was photographed at different time points ( $1 \mathrm{~d}, 2 \mathrm{~d}$ and $3 \mathrm{~d}$ ). Each wound was analyzed by measuring the distance migrated by cells in three different areas. Data are presented as the mean \pm standard deviation (SD) for experiments and compared to control miRNA transfected cells.

\subsection{Bioinformatics}

Potential miR-141-3p targets were predicted and analyzed using the following four publicly available algorithms: RNAhybrid (http://bibiserv.techfak.uni-bielefeld.de/rnahybrid), PicTar (http://pictar.mdc-berlin.de/), TargetScan (http://www.Targetscan.org), and 
miRanda (http://www.microrna.org/). Conservative analysis was performed by NCBI-blast (http://blast.ncbi.nlm.nih.gov/Blast.cgi).

\subsection{Statistical Analysis}

Statistical analyses of data were performed with SPSS 20.0. All data are expressed as the mean $\pm \mathrm{SD}$ of at least three separate experiments. All statistical tests were two-sided, and $P$-values $<0.05$ were considered to indicate statistical significance. Unless otherwise noted, the differences between groups were analyzed using either the unpaired Student's $t$-test when only two groups were compared or a one-way analysis of variance (ANOVA) when more than two groups were compared.

\section{Results}

\subsection{Aberrant Expression of miR-141-3p in Human Early PCa}

We previously investigated small RNA transcriptomes by deep-sequencing technology to evaluate three pooled libraries [9]. A total of 13,896,705,

$16,768,094$ and 17,184,337 raw sequence reads were produced for the malignant PCa $(G>7)$, early PCa $(G \leq 7)$, and BPH groups, respectively. After filtering out low quality reads and trimming off adaptors, 10,494,173, 14,577,221 and $14,614,835$ sequence reads were obtained [9]. The normalized counts of sequencing reads (specific miRNA/total sequencing tags in the library) were used to quantify miRNA expression levels among the PCa $(G>7), P C a(G \leq 7)$ and BPH groups. The statistical significance ( $P$-value) was inferred based on the Bayesian method, which was developed for analysis of digital gene expression profiles. We found a 1.26-fold reduction in miR-141-3p expression in early PCa compared to BPH $(P<0.05)$, while compared to the early PCa samples, the average miR-141-3p level increased by 3.90 -fold in advanced tumors $(P<0.05)$ (Figure 1(a)). A number of previous reports describe the effects of miR-141-3p overexpression in human PCa [4] [5] [6] [10], although reports of the effects of inhibited miR-141-3p expression in early PCa are rare.

To further validate the sequencing data, we independently chose 32 early $\mathrm{PCa}$, 14 malignant PCa and $16 \mathrm{BPH}$ tissues. Total RNAs were prepared and analyzed by qRT-PCR. We determined whether miR-141-3p downregulation was common in clinical early PCa tissues. The boxplot of qRT-PCR analyses is shown in Figure 1(b). The average miR-141-3p level was 1.17-fold less in early PCas than that in BPHs $(P=0.2053)$ (Figure $1(b))$. This may be due to the limited number of cases analyzed. Taken together, these data provide evidence that miR-141-3p expression is not evidently changed in early PCa.

\subsection{AR Is a Direct Target of miR-141-3p, and AR Levels Are Inversely Correlated with miR-141-3p Levels}

AR overexpression is well known to play an important role in the pathogenesis of PCa. We investigated whether certain miRNA(s) contribute to AR upregulation. From RNAhybrid 2.0 [11], we predicted that the region spanning 2563 - 


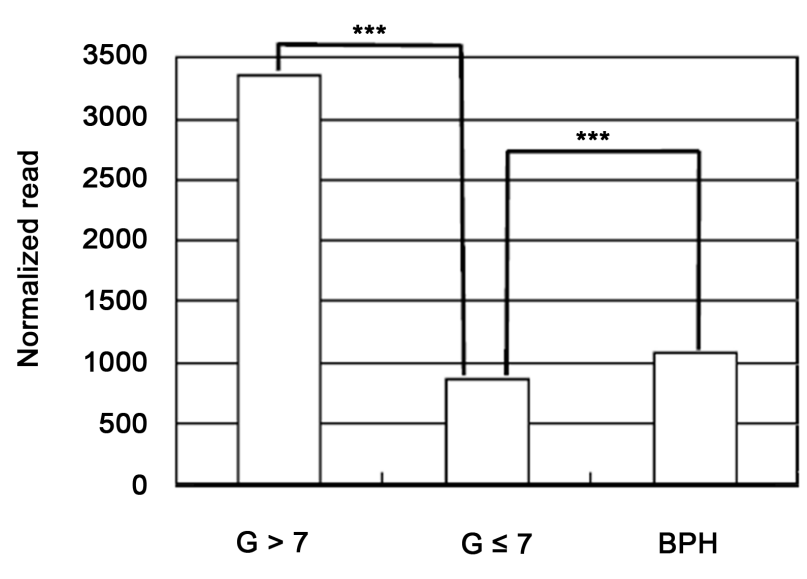

(a)

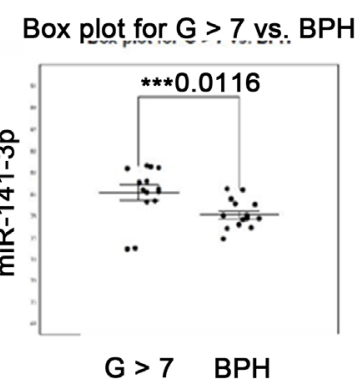

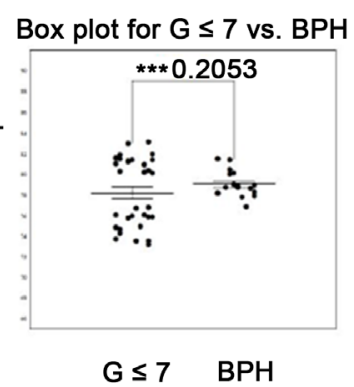

(b)

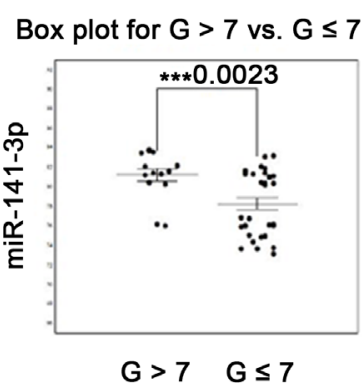

Figure 1. MiR-141-3p expression in human prostate cancer and benign prostatic hyperplasia (BPH). MiR-141-3p expression levels in tissues were defined by deep-sequencing (a) and qRT-PCR (b). The average expression difference between early tumors and noncancerous tissues was deceased by 1.26-fold (a) and 1.17-fold (b), while the expression difference between malignant and early tumors was increased by 6.7 -fold (A) and 1.5-fold (b). MiR-141-3p expression levels were not evidently changed in early prostate tumor tissues compared with those the BPH tissues. (a) MiR-141-3p expression levels were assessed by deep-sequencing in noncancerous tissues $(n=9)$, early tumors $(G \leq 7, n=8)$, and malignant tumors $(\mathrm{G}>7, \mathrm{n}=7$ ); (b) MiR-141-3p expression levels were analyzed in 32 FFPE tissues of early PCa $(G \leq 7), 14$ malignant PCa tissues $(G>7)$ and 16 BPH tissues using qRT-PCR. U6 small nuclear RNA was used as an internal control. Horizontal lines indicate the median. A Student's $t$-test was used to analyze significant differences among the groups. $\left.{ }^{* * *}\right)$ Significant difference when compared with control tissues $(P<$ $0.05)$.

2585 bp of the AR mRNA (GenBank: M23263.1) was a potential miR-141-3p binding site (Figure 2(a)). Sequence alignment of this putative site showed evolutionary conservation within mammalian species and AR mutants (Table 1).

To verify that the putative miR-141-3p binding site in the ORF of AR mRNA is responsible for regulation by miR-141-3p, the region spanning $2550-3000 \mathrm{bp}$ of the AR ORF (5'-GCCATTGAGCCAGGTGTAGTGTG-3') and its mutant (5'-GCCA------AG-3') were cloned separately into the pmirGLO luciferase reporter vector, and then cotransfected with the miR-141-3p mimic or control miR-NC into 293T cells. Luciferase activity was measured after two days. As shown in Figure 2(b), the miR-141-3p mimic significantly reduced luciferase levels when cotransfected with the wild-type AR ORF (8.9\% inhibition, $P<$ 
(a)

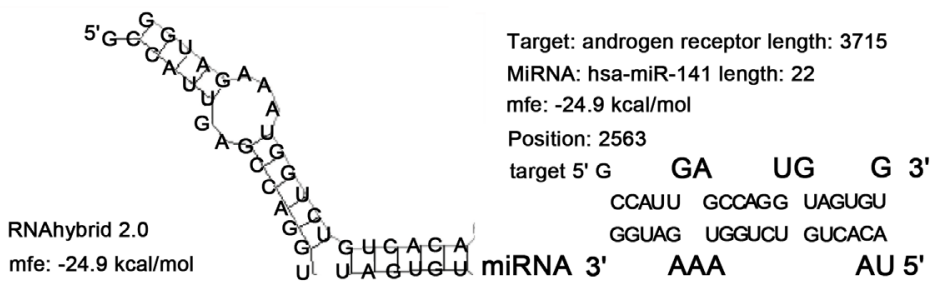

(b)
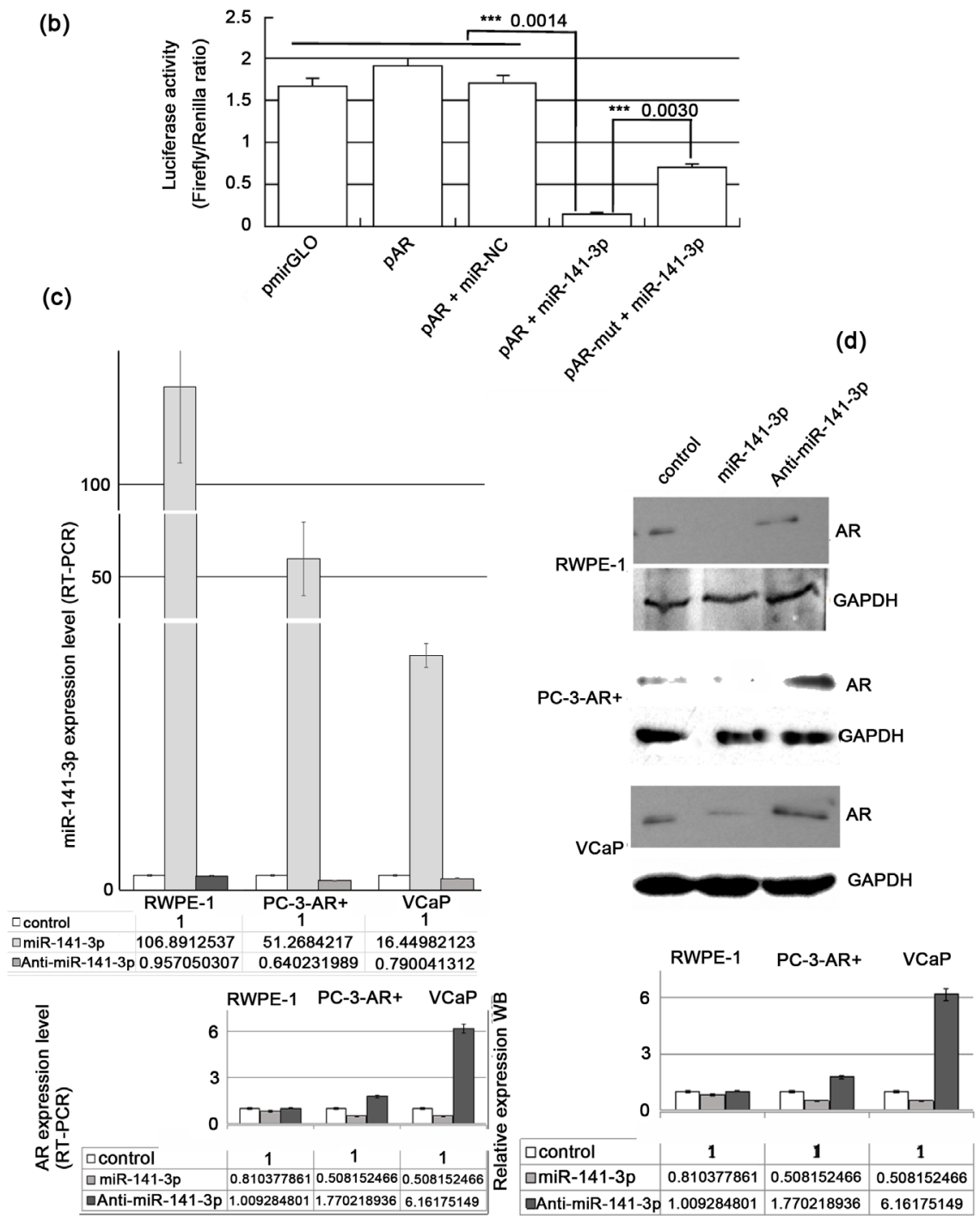

Figure 2. AR is a direct target of miR-141-3p, and AR levels are inversely correlated with miR-141-3p levels in RWPE-1 cells. (a) The region spanning 2563 - 2585 bp of the AR ORF (GenBank: M23263.1) was predicted as a potential miR-141-3p-binding site by RNAhybrid v2.0 software; (b) Relative luciferase activities were obtained by cotransfection of the miR-141-3p mimic or control miR-NC and pmirGLO reporter plasmids including AR-WT and AR-Mut, and calculated as the ratio of firefly/Renilla activities and normalized to those of the control; (c) MiR-141-3p and AR expression levels in RWPE-1, PC-3 and VCaP cells were determined by qRT-PCR analyses. Data represent the mean \pm $\mathrm{SD}$ of three independent experiments; (d) The expression levels of AR in transfected RWPE-1. PC-3 and VCaP cells were detected by WB, and fold changes were calculated as the ratio of AR and GAPDH levels. Overexpression of miR-141-3p inhibited AR expression at the mRNA and protein levels, while miR-141-3p knockdown resulted in recovery of AR expression at both the mRNA and protein levels. 
Table 1. The conservation analysis of miR-141-3p binding site in the AR ORF.

\begin{tabular}{|c|c|c|c|c|c|c|}
\hline Description & $\begin{array}{l}\text { Max } \\
\text { score }\end{array}$ & $\begin{array}{l}\text { Total } \\
\text { score }\end{array}$ & $\begin{array}{l}\text { Query } \\
\text { cover }\end{array}$ & E value & Ident & Accession \\
\hline Homo sapiens androgen receptor (AR), mRNA & 46.1 & 46.1 & $100 \%$ & 0.004 & $100 \%$ & NM_001011645.2 \\
\hline $\begin{array}{l}\text { Homo sapiens isolate } \mathrm{AR} \_758 \text { mutant } \\
\text { androgen receptor }(\mathrm{AR}) \text { isoform } 1 \text {, complete cds }\end{array}$ & 46.1 & 46.1 & $100 \%$ & 0.004 & $100 \%$ & HM010955.1 \\
\hline $\begin{array}{l}\text { Homo sapiens isolate AR_579 androgen } \\
\text { receptor (AR) isoform 1, complete cds }\end{array}$ & 46.1 & 46.1 & $100 \%$ & 0.004 & $100 \%$ & GU784859.1 \\
\hline $\begin{array}{l}\text { Homo sapiens isolate AR_649 androgen } \\
\text { receptor }(\mathrm{AR}) \text { isoform } 1 \text {, complete cds }\end{array}$ & 46.1 & 46.1 & $100 \%$ & 0.004 & $100 \%$ & GU784858.1 \\
\hline $\begin{array}{l}\text { Homo sapiens isolate } \mathrm{AR} \_142 \text { androgen } \\
\text { receptor }(\mathrm{AR}) \text { isoform } 1, \text { complete cds }\end{array}$ & 46.1 & 46.1 & $100 \%$ & 0.004 & $100 \%$ & GU784857.1 \\
\hline $\begin{array}{l}\text { Homo sapiens isolate } \mathrm{AR} \_277 \text { androgen } \\
\text { receptor }(\mathrm{AR}) \text { isoform } 1 \text {, complete cds }\end{array}$ & 46.1 & 46.1 & $100 \%$ & 0.004 & $100 \%$ & GU784856.1 \\
\hline $\begin{array}{l}\text { Homo sapiens isolate } \mathrm{AR} \_395 \text { androgen } \\
\text { receptor }(\mathrm{AR}) \text { isoform } 1 \text {, complete cds }\end{array}$ & 46.1 & 46.1 & $100 \%$ & 0.004 & $100 \%$ & GU784855.1 \\
\hline $\begin{array}{l}\text { Homo sapiens isolate } A R \_473 \text { androgen } \\
\text { receptor }(\mathrm{AR}) \text { isoform } 1, \text { complete cds }\end{array}$ & 46.1 & 46.1 & $100 \%$ & 0.004 & $100 \%$ & GU373805.1 \\
\hline $\begin{array}{l}\text { Homo sapiens androgen receptor variant } \\
5,6,7 \text { es (AR) mRNA, alternatively spliced }\end{array}$ & 46.1 & 46.1 & $100 \%$ & 0.004 & $100 \%$ & GU208210.1 \\
\hline Androgen receptor [human, Genomic Mutant, $370 \mathrm{nt}$ ] & 46.1 & 46.1 & $100 \%$ & 0.004 & $100 \%$ & S79368.1 \\
\hline Nomascus leucogenys androgen receptor (AR), mRNA & 46.1 & 46.1 & $100 \%$ & 0.004 & $100 \%$ & XM_003272706.3 \\
\hline Pongo abelii androgen receptor (AR), mRNA & 46.1 & 46.1 & $100 \%$ & 0.004 & $100 \%$ & XM_009234939.1 \\
\hline Pan paniscus androgen receptor (AR), mRNA & 46.1 & 46.1 & $100 \%$ & 0.004 & $100 \%$ & XM_003816907.2 \\
\hline Ochotona princeps androgen receptor (AR), mRNA & 46.1 & 46.1 & $100 \%$ & 0.004 & $100 \%$ & XM_004595204.1 \\
\hline Crocuta crocuta androgen receptor mRNA & 46.1 & 46.1 & $100 \%$ & 0.004 & $100 \%$ & AY128705.1 \\
\hline $\begin{array}{l}\text { Wallabia bicolor androgen receptor } \\
\text { (AR) gene, exon } 4 \text { and partial cds }\end{array}$ & 46.1 & 46.1 & $100 \%$ & 0.004 & $100 \%$ & AF081532.1 \\
\hline Pan troglodytes androgen receptor (AR), mRNA & 46.1 & 46.1 & $100 \%$ & 0.004 & $100 \%$ & NM_001009012.1 \\
\hline $\begin{array}{l}\text { Gorilla gorilla gorilla androgen } \\
\text { receptor-like (LOC101143627), mRNA }\end{array}$ & 40.1 & 40.1 & $86 \%$ & 0.26 & $100 \%$ & XM_004064298.1 \\
\hline Sus scrofa androgen receptor (AR), mRNA & 38.2 & 38.2 & $100 \%$ & 1.0 & $96 \%$ & XM_013986227.1 \\
\hline Ictidomys tridecemlineatus androgen receptor (AR), mRNA & 38.2 & 38.2 & $100 \%$ & 1.0 & $96 \%$ & XM_005335195.2 \\
\hline Aotus nancymaae androgen receptor (AR), mRNA & 38.2 & 38.2 & $100 \%$ & 1.0 & $96 \%$ & XM_012460838.1 \\
\hline Macaca nemestrina androgen receptor (AR), mRNA & 38.2 & 38.2 & $100 \%$ & 1.0 & $96 \%$ & XM_011732842.1 \\
\hline Cercocebus atys androgen receptor (AR), mRNA & 38.2 & 38.2 & $100 \%$ & 1.0 & $96 \%$ & XM_012060885.1 \\
\hline Colobus angolensis palliatus androgen receptor (AR), mRNA & 38.2 & 38.2 & $100 \%$ & 1.0 & $96 \%$ & XM_011961988.1 \\
\hline Mandrillus leucophaeus androgen receptor (AR), mRNA & 38.2 & 38.2 & $100 \%$ & 1.0 & $96 \%$ & XM_011980535.1 \\
\hline $\begin{array}{l}\text { Rhinopithecus roxellana androgen } \\
\text { receptor (LOC104668178), mRNA }\end{array}$ & 38.2 & 38.2 & $100 \%$ & 1.0 & $96 \%$ & XM_010370828.1 \\
\hline Papio anubis androgen receptor (AR), mRNA & 38.2 & 38.2 & $100 \%$ & 1.0 & $96 \%$ & XM_003917817.2 \\
\hline Fukomys damarensis androgen receptor (AR) mRNA, partial cds & 38.2 & 38.2 & $100 \%$ & 1.0 & $96 \%$ & KF574039.1 \\
\hline Chlorocebus sabaeus androgen receptor (AR), mRNA & 38.2 & 38.2 & $100 \%$ & 1.0 & $96 \%$ & XM_007991938.1 \\
\hline
\end{tabular}




\section{Continued}

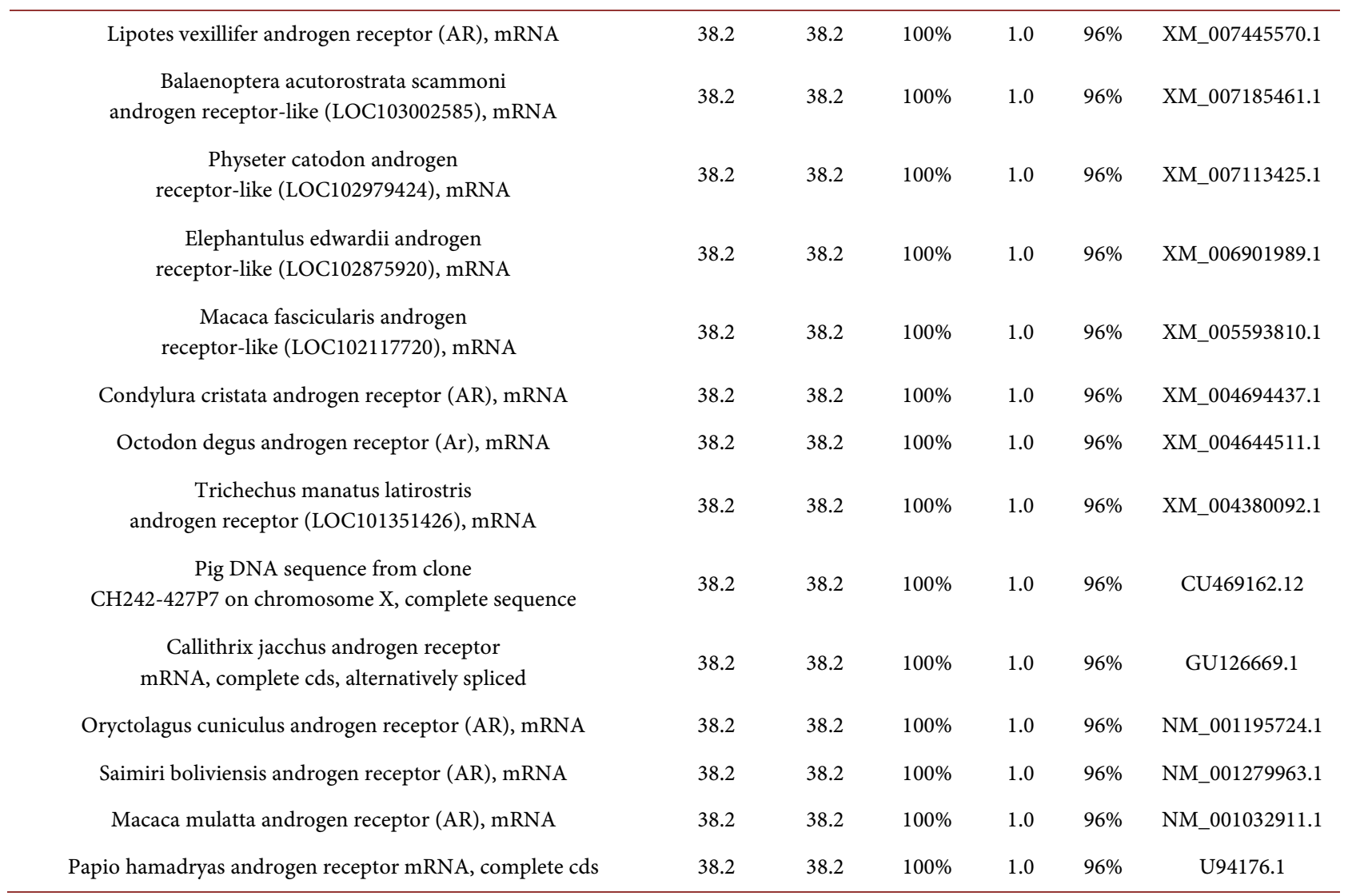

0.05), but not with the mutant AR ORF, indicating a direct interaction between miR-141-3p and AR mRNA.

To further confirm that miR-141-3p downregulates the levels of AR mRNA and protein, RWPE-1, PC-3 and VCaP cells were transfected with the miR-141$3 p$ mimic or control miR-NC, and AR mRNA and protein levels were evaluated by qRT-PCR and WB analyses, respectively (Figure 2(c) and Figure 2(d)). Our data showed that miR-141-3p downregulated AR mRNA and protein levels. Similarly, miR-141-3p knockdown led to recovered AR expression in these cells (Figure 2(c) and Figure 2(d)). Taken together, these data indicate that miR141-3p targets the AR and affects AR activity.

\subsection{MiR-141-3p Inhibits Prostate Epithelial Cell Proliferation and Mobility}

To analyze the role of miR-141-3p in early progression of human PCa, we upregulated or downregulated miR-141-3p to observe its influence on cell proliferation, cell cycle and mobility ability. We chose immortalized normal human prostatic epithelial cell line RWPE-1 cells to study the functions of miR-141-3p, because the genome and phenotype of these cells are similar to those of normal prostatic epithelial cells. In this cellular system, we were able to reproduce the development process of early PCa induced by miR-141-3p and AR. RWPE-1 cells were transfected with the miR-141-3p mimic or miR-NC, and analyzed for 
cell growth, cell cycle and mobility. MiR-141-3p-transfected RWPE-1 cells expressed the miRNA at a level 106-fold higher than that of the control (Figure $2(c))$. Proliferation assays showed that cell growth was reduced in miR-141-3ptransfected cells compared with miR-NC-transfected control cells (Figure 3(a)). In FCM analysis, the percentage of cells in the G0/G1 phase increased from $73.29 \%$ in controls to $75.75 \%$ in miR-141-3p-transfected cells, whereas the percentage of cells in S phase decreased from $18.70 \%$ to $16.20 \%$ (Figure 3(b)), indicating that miR-141-3p overexpression effectively inhibited the transition from $\mathrm{G}_{0} / \mathrm{G}_{1}$ to $\mathrm{G} 2-\mathrm{S}-\mathrm{M}$ phase in the progression of human early PCa. We analyzed the effect of miR-141-3p overexpression on the mobility behavior of RWPE-1 cells. MiR-141-3p overexpression decreased the mobility of cells (Figure 4). In loss experiments of miR-141-3p, miR-141-3p knockdown led to enhanced cell growth and mobility as shown in Figure 3 and Figure 4.

(a)

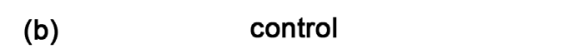

RWPE-1

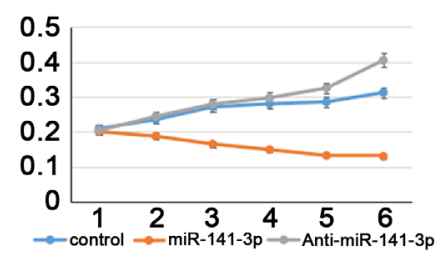

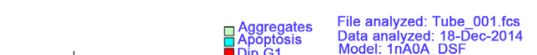
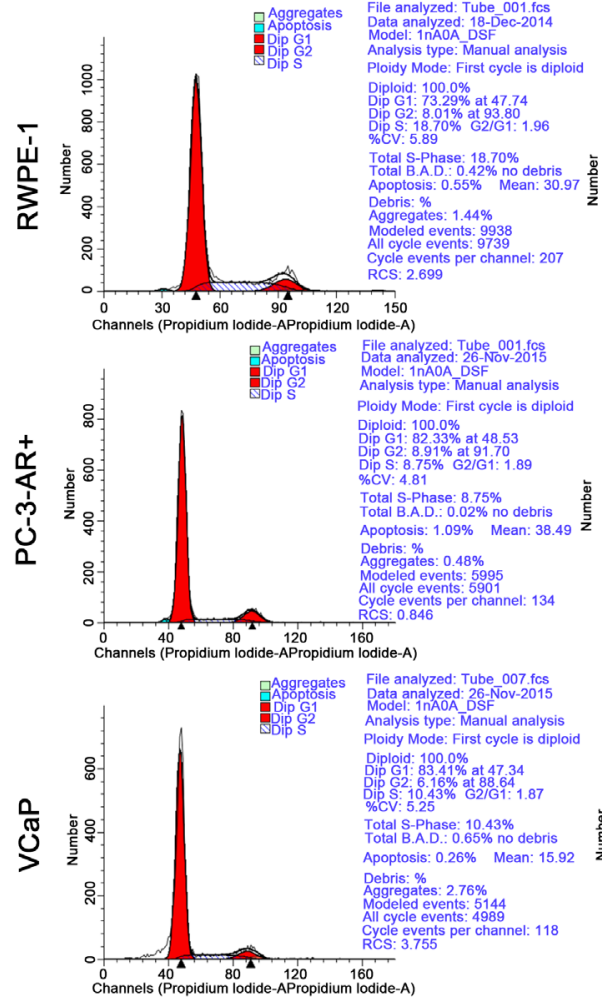

PC-3-AR+

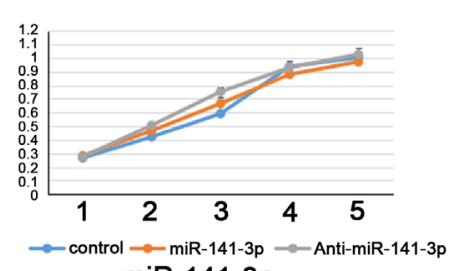
miR-141-3p
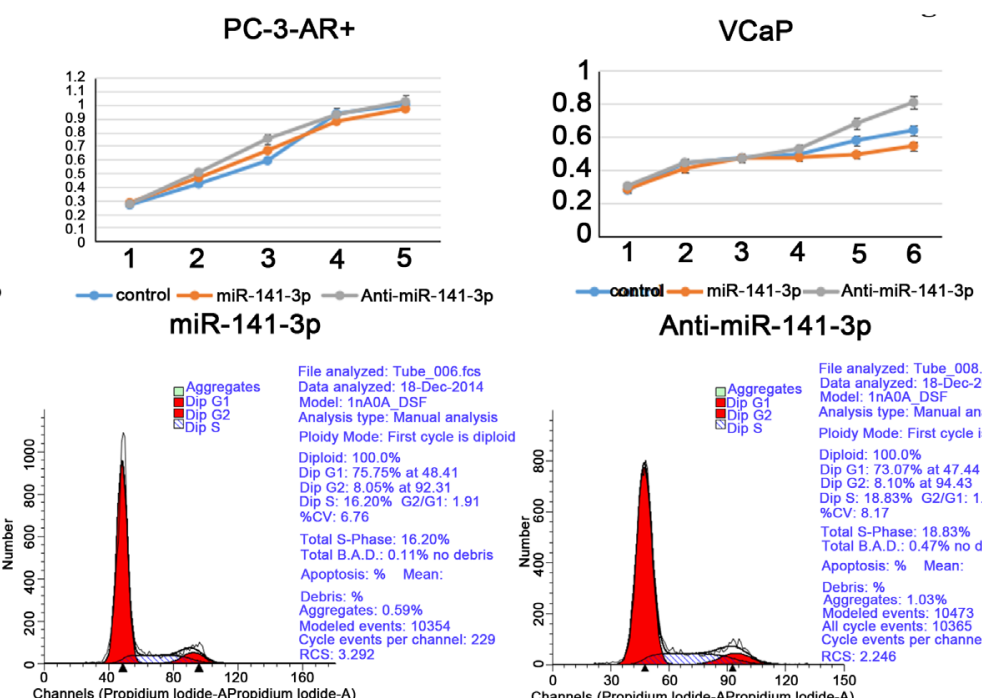

Anti-miR-141-3p

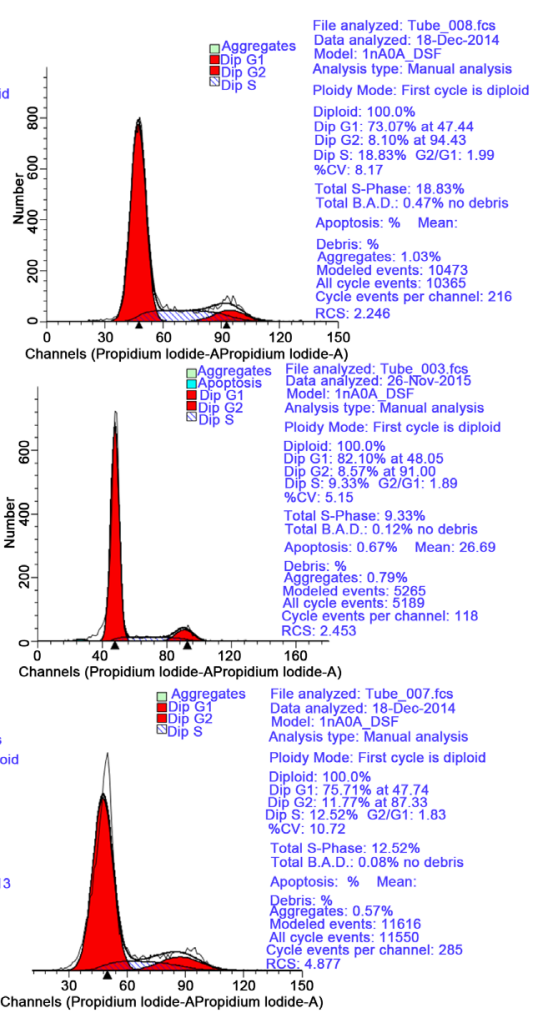

Figure 3. MiR-141-3p inhibits cell proliferation in vitro. (a) Cell growth curves were generated based on MTT assay data. Transfected cells were seeded at 3000 cells per well in a 96-well plate. Absorbance was measured at the indicated time points using a BioRad Model 680 microplate reader. Data represent the average of three independent experiments; (b) Cell cycle distribution of transfected cells with the miR-141-3p mimic or inhibitor or miR-NC. Overexpression of miR-141-3p hindered the G1 to G2-S-M cell cycle transition. 


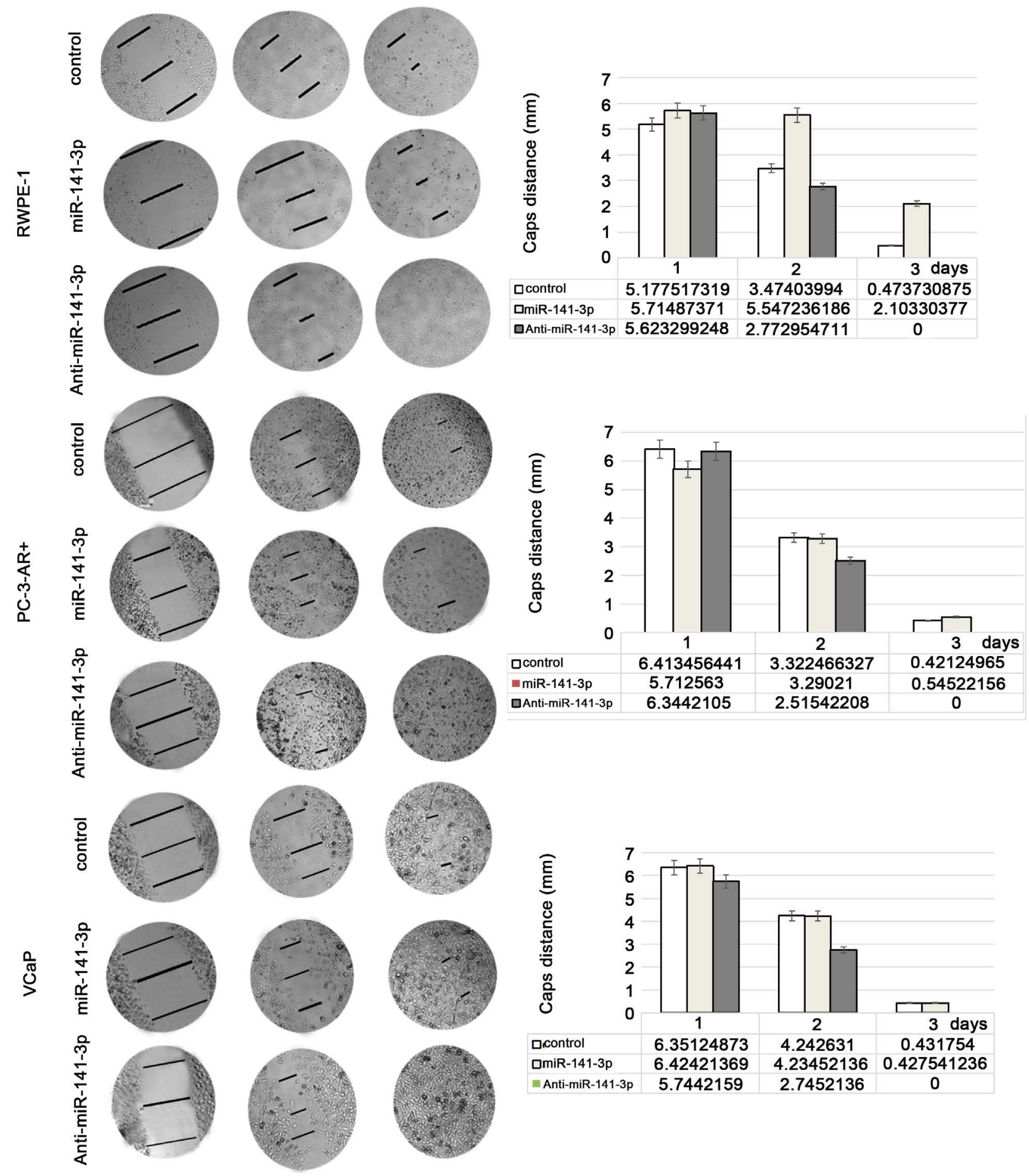

Figure 4. MiR-141-3p inhibits cell mobility in vitro. RWPE-1, PC-3 and VCaP cell wound-healing assays. The wound gaps were photographed and measured in three different areas. Wound-healing assays indicated that AR downregulation inhibited cell mobility.

To further evaluate the association of miR-141-3p with PCa progression, we chose two human malignant prostate cancer cell lines PC-3 and VCaP to assay their cell growth, cell cycle and mobility. As shown in Figure 3 and Figure 4, the same alteration was observed, but miR-141-3p's effection to cell functions in 
PC-3 and VCaP cells was slightly compared to that in RWPE-1 cells.

\section{Discussion}

Although the prostate is dependent on androgens for growth and development, certain growth restriction mechanisms exist in the normal state to avert androgen-induced over-growth. It is imperative to reveal how AR mediates these actions and breaks the growth restriction mechanisms, leading to prostate carcinogenesis. Thus, in this study, we attempted to systematically identify miRNAs that bridge the AR pathways to exert the cellular phenotypic effect in PCa. To study how miRNAs regulate AR signaling, it is necessary to identify their targets. Seed-sequence-based predictions, such as TargetScan, miRanda, RNAhybrid and PicTar databases, provide necessary information to identify the actual miRNA targets. MiR-141-3p is androgen regulated in PCa cell lines and xenografts [12], and modulates transcriptional activity of AR by targeting the small heterodimer partner protein (Shp), a corepressor to AR [13]. Additionally, Wang et al. found that miR-141-3p regulated the expression of androgen receptor by targeting its 3'UTR in prostate cancer LNCaP cells [14]. In our study, we found that miR141-3p bound specifically to the region spanning $256-2585$ bp of the AR ORF to decrease the levels of AR mRNA and protein. Moreover, miR-141-3p is reported to be significantly overexpressed in serum from CRPC patients compared with serum from low-risk localized patients. In high-risk prostate tumor samples, miR-141 is also expressed at significantly higher levels compared with those in normal prostate tissues [4] [6], and elevated serum miR-141-3p levels are observed in patients with metastatic PCa [5] [10]; however, few studies describe the changes in miR-141-3p expression in the early stages of the disease. Hizir et al. [15] reported that miR-141-3p expression is at normal levels in early PCa, which is in accordance with our findings. Using deep-sequencing analysis, we found that miR-141-3p expression was decreased by 1.26 -fold in early PCa compared to that in $\mathrm{BPH}(P<0.05)$, and confirmed a similar 1.17 -fold decrease in early PCa compared to that in BPH $(P=0.2053)$ by qRT-PCR. In addition, miR-141$3 p$ expression levels vary in different tumors, with overexpression observed in bladder [16], urothelial [17], breast [18] [19], ovarian [20], endometrioid [21], cholangiocytes [22] and colorectal cancers [23] and NSCLC [24], while expression is downregulated in gastric cancer [25], hepatocellular carcinomas [26] [27], renal cell carcinoma [28], lymphatic metastatic pancreatic cancer [29], pituitary tumors [30], craniopharyngioma [31], head and neck cancer [32], osteosarcoma [33], and cutaneous $\mathrm{T}$ cell lymphoma [34]. These reports provide compelling evidence for a role of miR-141-3p as an oncogene or tumor suppressor in different tumors and at different stages.

The results of our biological experimental validation reveal several interesting and novel mechanisms that significantly contribute to PCa cell survival and pathogenesis. Our present study also revealed some possible mechanisms by which androgen growth restriction is disrupted. Although we focus on AR in this study, we realize that miR-141-3p targets hundreds of human genes (Table 2), 
Table 2. Validated target genes of miR-141-3p.

\begin{tabular}{|c|c|}
\hline MicTarBase 4.5 & TarBase 7.0 \\
\hline 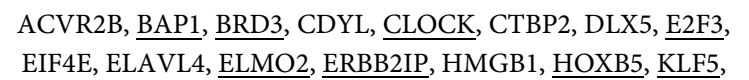 & BAP1, BRD3, CLOCK, CyclinD1, DP2, E2F3, ELMO2, ERBB2IP, \\
\hline $\begin{array}{l}\text { KLF11, KLHL20, MAP2K4, MAPK9, MAPK14, NR0B2, PPARA, } \\
\text { PTEN, PTPRD, RASSF2, RIN2, SEPT7, SERBP1, SFPQ, SHC1, }\end{array}$ & $\begin{array}{l}\text { HOXB5, HuD, JNK2, KLF5, KLF11, KLHL20, MAP4K4, PTEN, } \\
\text { PTPRD, RASSF2, RIN2, SEPT7, SFPQ, SHC1, STK3, TCF7L1, }\end{array}$ \\
\hline $\begin{array}{l}\text { SIP1, } \underline{\text { STK3 }}, \frac{\text { TCF7L1, TFDP2, TGFB2, TRAPPC2P1, UBAP1, }}{\text { VAC14, WDR37, YWHAG, ZEB1, ZEB2, ZFPM2, }}\end{array}$ & $\underline{\text { TGFB2}}, \underline{\text { UBAP1}}, \underline{\text { VAC14}}, \underline{\text { WDR37, }} \underline{\text { YWHAG, }} \underline{\text { ZEB11, ZEB2 }}$ \\
\hline
\end{tabular}

Lineation emphasized target genes which are recorded by two databases.

and other targets may also be relevant in the tumor suppressive function of miR-141-3p in PCa. Although AR was the predicted as a direct target of miR141-3p according to our data, PTEN and TCF7L1, which are involved in G1/S progression, and E2F3, which is involved in cell proliferation, have also been identified as miR-141-3p targets, and may also be involved in the PCa signaling pathways.

\section{Conclusion}

In this study, we show that miR-141-3p expression does not change in early PCas. MiR-141-3p negatively regulates AR expression, and miR-141-3p down regulation increases expression of AR. Therefore, we propose that deregulation of miR-141-3p contributes to the high levels of AR expression in clinical PCas. Additionally, our data suggest that miR-141-3p down regulation contributes to the pathogenesis of PCa.

\section{Acknowledgements}

This work was supported by Zhejiang Provincial Science Technology Program of China (2013C33101), Zhejiang Medical Platform Program (2015RCA023), Zhejiang Provincial National Science Foundation of China (LQ12H16007), and Zhejiang Provincial Science Technology Program of China (2012C23097).

\section{Conflict of Interest}

The authors disclose no potential conflicts of interest.

\section{Funds}

This work was supported by Zhejiang Provincial Science Technology Program of China (2013C33101), Zhejiang medical platform program (2015RCA023), Zhejiang Provincial National Science Foundation of China (LQ12H16007), and Zhejiang Provincial Science Technology Program of China (2012C23097).

\section{References}

[1] Carlsson, S., Vickers, A.J., Roobol, M., Eastham, J., Scardino, P., Lilja, H. and Hugosson, J. (2012) Prostate Cancer Screening: Facts, Statistics, and Interpretation in Response to the US Preventive Services Task Force Review. Journal of Clinical Oncology, 30, 2581-2584. https://doi.org/10.1200/jco.2011.40.4327 
[2] Siegel, R., Naishadham, D. and Jemal, A. (2013) Cancer Statistics, 2013. CA: A Cancer Journal for Clinicians, 63, 11-30. https://doi.org/10.3322/caac.21166

[3] Chun, J., Huan, C., Chao, Y.X. and Guo, M.R. (2014) Uncovering the Roles of miRNAs and Their Relationship with Androgen Receptor in Prostate Cancer. IUBMB Life, 66, 379-386. https://doi.org/10.1002/iub.1281

[4] Westermann, A.M., Schmidt, D., Holdenrieder, S., Moritz, R., Semjonow, A., Schmidt, M., Kristiansen, G., Müller, S.C. and Ellinger, J. (2014) Serum microRNAs as Biomarkers in Patients Undergoing Prostate Biopsy: Results from a Prospective Multi-Center Study. Anticancer Research, 34, 665-669.

[5] Zhang, H.L., Qin, X.J., Cao, D.L., Zhu, Y., Yao, X.D., Zhang, S.L., Dai, B. and Ye, D.W. (2013) An Elevated Serum miR-141 Level in Patients with Bone-Metastatic Prostate Cancer Is Correlated with More Bone Lesions. Asian Journal of Andrology, 15, 231-235. https://doi.org/10.1038/aja.2012.116

[6] Nguyen, H.C., Xie, W., Yang, M., Hsieh, C.L., Drouin, S., Lee, G.S. and Kantoff, P.W. (2013) Expression Differences of Circulating microRNAs in Metastatic Castration Resistant Prostate Cancer and Low-Risk, Localized Prostate Cancer. Prostate, 73, 346-354. https://doi.org/10.1002/pros.22572

[7] Selth, L.A., Townley, S., Gillis, J.L., Ochnik, A.M., Murti, K., Macfarlane, R.J., Chi, K.N., Marshall, V.R., Tilley, W.D. and Butler, L.M. (2012) Discovery of Circulating microRNAs Associated with Human Prostate Cancer Using Amouse Model of Disease. International Journal of Cancer, 131, 652-661. https://doi.org/10.1002/ijc.26405

[8] Mitchell, P.S., Parkin, R.K., Kroh, E.M., Fritz, B.R., Wyman, S.K., Pogosova-Agadjanyan, E.L., Peterson, A., Noteboom, J., O’Briant, K.C., Allen, A., Lin, D.W., Urban, N., Drescher, C.W., Knudsen, B.S., Stirewalt, D.L., Gentleman, R., Vessella, R.L., Nelson, P.S., Martin, D.B. and Tewari, M. (2008) Circulating micrornas as Stable Blood-Based Markers for Cancer Detection. Proceedings of the National Academy of Sciences of the United States of America, 105, 10513-10518. https://doi.org/10.1073/pnas.0804549105

[9] Song, C., Chen, H., Wang, T., Zhang, W., Ru, G. and Lang, J. (2015) Expression Profile Analysis of microRNAs in Prostate Cancer by Next-Generation Sequencing. Prostate, 75, 500-516. https://doi.org/10.1002/pros.22936

[10] Bryant, R.J., Pawlowski, T., Catto, J.W., Marsden, G., Vessella, R.L., Rhees, B., Kuslich, C., Visakorpi, T. and Hamdy, F.C. (2012) Changes in Circulating microRNA Levels Associated with Prostate Cancer. British Journal of Cancer, 106, 768-774. https://doi.org/10.1038/bjc.2011.595

[11] Marc, R., Peter, S., Matthias, H. and Robert, G. (2004) Fast and Effective Prediction of microRNA/Target Duplexes. RNA, 10, 1507-1517.

https://doi.org/10.1261/rna.5248604

[12] Waltering, K.K., Porkka, K.P., Jalava, S.E., Urbanucci, A., Kohonen, P.J., Latonen, L.M., Kallioniemi, O.P., Jenster, G. and Visakorpi, T. (2011) Androgen Regulation of Micro-RNAs in Prostate Cancer. Prostate, 71, 604-614. https://doi.org/10.1002/pros.21276

[13] Xiao, J., Gong, A.Y., Eischeid, A.N., Chen, D., Deng, C., Young, C.Y. and Chen, X.M. (2012) MiR-141 Modulates Androgen Receptor Transcriptional Activity in Human Prostate Cancer Cells through Targeting the Small Heterodimer Partner Protein. Prostate, 72, 1514-1522. https://doi.org/10.1002/pros.22501

[14] Wang, C., Ouyang, Y., Lu, M., Wei, J. and Zhang, H. (2015) MiR-141-3p Regulates the Expression of Androgen Receptor by Targeting Its 3'UTR in Prostate Cancer LNCaP Cells. Chinese Journal of Cellular and Molecular Immunology, 31, 736-739. 
[15] Hizir, M.S., Balcioglu, M., Rana, M., Robertson, N.M. and Yigit, M.V. (2014) Simultaneous Detection of Circulating on comiRs from Body Fluids for Prostate Cancer Staging Using Nanographene Oxide. ACS Applied Materials \& Interfaces, 6 , 14772-14778.

[16] Ratert, N., Meyer, H.A., Jung, M., Lioudmer, P., Mollenkopf, H.J., Wagner, I., Miller, K., Kilic, E., Erbersdobler, A., Weikert, S. and Jung, K. (2013) MiRNA Profiling Identifies Candidate Mirnas for Bladder Cancer Diagnosis and Clinical Outcome. Journal of Molecular Diagnostics, 15, 695-705. https://doi.org/10.1016/j.jmoldx.2013.05.008

[17] Kriebel, S., Schmidt, D., Holdenrieder, S., Goltz, D., Kristiansen, G., Moritz, R., Fisang, C., Müller, S.C. and Ellinger, J. (2015) Analysis of Tissue and Serum microRNA Expression in Patients with Upper Urinary Tract Urothelial Cancer. PLoS $O N E, 10$, e0117284. https://doi.org/10.1371/journal.pone.0117284

[18] Chen, L., Li, Y., Fu, Y., Peng, J., Mo, M.H., Stamatakos, M., Teal, C.B., Brem, R.F., Stojadinovic, A., Grinkemeyer, M., McCaffrey, T.A., Man, Y.G. and Fu, S.W. (2013) Role of Deregulated microRNAs in Breast Cancer Progression Using FFPE Tissue. PLoS ONE, 8, e54213. https://doi.org/10.1371/journal.pone.0054213

[19] Madhavan, D., Zucknick, M., Wallwiener, M., Cuk, K., Modugno, C., Scharpff, M., Schott, S., Heil, J., Turchinovich, A., Yang, R., Benner, A., Riethdorf, S., Trumpp, A., Sohn, C., Pantel, K., Schneeweiss, A. and Burwinkel, B. (2012) Circulating miRNAs as Surrogate Markers for Circulating Tumor Cells and Prognostic Markers in Metastatic Breast Cancer. Clinical Cancer Research, 18, 5972-5982. https://doi.org/10.1158/1078-0432.CCR-12-1407

[20] Nam, E.J., Yoon, H., Kim, S.W., Kim, H., Kim, Y.T., Kim, J.H., Kim, J.W. and Kim, S. (2008) MicroRNA Expression Profiles in Serous Ovarian Carcinoma. Clinical Cancer Research, 14, 2690-2695. https://doi.org/10.1158/1078-0432.CCR-07-1731

[21] Lee, T.S., Jeon, H.W., Kim, Y.B., Kim, Y.A., Kim, M.A. and Kang, S.B. (2013) Aberrant microRNA Expression in Endometrial Carcinoma Using Formalin-Fixed Paraffin-Embedded (FFPE) Tissues. PLoS ONE, 8, e81421. https://doi.org/10.1371/journal.pone.0081421

[22] Meng, F., Henson, R., Lang, M., Wehbe, H., Maheshwari, S., Mendell, J.T., Jiang, J., Schmittgen, T.D. and Patel, T. (2006) Involvement of Human Micro-RNA in Growth and Response to Chemotherapy in Human Cholangio-Carcinoma Cell Lines. Gastroenterology, 130, 2113-2129. https://doi.org/10.1053/j.gastro.2006.02.057

[23] Yin, J., Bai, Z., Song, J., Yang, Y., Wang, J., Han, W., Zhang, J., Meng, H., Ma, X., Yang, Y., Wang, T., Li, W. and Zhang, Z. (2014) Differential Expression of Serum miR-126, miR-141 and miR-21 as Novel Biomarkers for Early Detection of Liver Metastasis in Colorectal Cancer. Chinese Journal of Cancer Research, 26, 95-103.

[24] Liu, X.G., Zhu, W.Y., Huang, Y.Y., Ma, L.N., Zhou, S.Q., Wang, Y.K., Zeng, F., Zhou, J.H. and Zhang, Y.K. (2012) High Expression of Serum miR-21 and Tumor miR-200c Associated with Poor Prognosis in Patients with Lung Cancer. Medical Oncology, 29, 618-626. https://doi.org/10.1007/s12032-011-9923-y

[25] Zhou, X., Wang, Y., Shan, B., Han, J., Zhu, H., Lv, Y., Fan, X., Sang, M., Liu, X.D. and Liu, W. (2015) The Downregulation of miR-200c/141 Promotes ZEB1/2 Expression and Gastric Cancer Progression. Medical Oncology, 32, 428. https://doi.org/10.1007/s12032-014-0428-3

[26] Tan, Y., Ge, G., Pan, T., Wen, D., Chen, L., Yu, X., Zhou, X. and Gan, J. (2014) A Serum microRNA Panel as Potential Biomarkers for Hepatocellular Carcinoma Related with Hepatitis B Virus. PLOS ONE, 9, e107986. 
https://doi.org/10.1371/journal.pone.0107986

[27] Yeh, T.S., Wang, F., Chen, T.C., Yeh, C.N., Yu, M.C., Jan, Y.Y. and Chen, M.F. (2014) Expression Profile of microRNA-200 Family in Hepatocellular Carcinoma with Bile Duct Tumor Thrombus. Annals of Surgery, 259, 346-354.

https://doi.org/10.1097/SLA.0000000000000223

[28] Chen, X., Wang, X., Ruan, A., Han, W., Zhao, Y., Lu, X., Xiao, P., Shi, H., Wang, R., Chen, L., Chen, S., Du, Q., Yang, H. and Zhang, X. (2014) MiR-141 Is a Key Regulator of Renal Cell Carcinoma Proliferation and Metastasis by Controlling EphA2 Expression. Clinical Cancer Research, 20, 2617-2630. https://doi.org/10.1158/1078-0432.CCR-13-3224

[29] Luo, G., Long, J., Cui, X., Xiao, Z., Liu, Z., Shi, S., et al. (2013) Highly Lymphatic Metastatic Pancreatic Cancer Cells Possess Stem Cell-Like Properties. International Journal of Oncology, 42, 979-984.

[30] Amaral, F.C., Torres, N., Saggioro, F., Neder, L., Machado, H.R., Silva, W.A., Moreira, A.C. and Castro, M. (2009) MicroRNAs Differentially Expressed in ACTHSecreting Pituitary Tumors. Journal of Clinical Endocrinology \& Metabolism, 94, 320-323. https://doi.org/10.1210/jc.2008-1451

[31] Campanini, M.L., Colli, L.M., Paixao, B.M., Cabral, T.P., Amaral, F.C., Machado, H.R., Neder, L.S., Saggioro, F., Moreira, A.C., Antonini, S.R. and de Castro, M. (2010) CTNNB1 Gene Mutations, Pituitary Transcription Factors, and MicroRNA Expression Involvement in the Pathogenesis of Adamantinomatous. Hormones and Cancer, 1, 187-196. https://doi.org/10.1007/s12672-010-0041-7

[32] Nurul-Syakima, A.M., Yoke-Kqueen, C., Sabariah, A.R., Shiran, M.S., Singh, A. and Learn-Han, L. (2011) Differential microRNA Expression and Identification of Putative miRNA Targets and Pathways in Head and Neck Cancers. International Journal of Molecular Medicine, 28, 327-336.

[33] Xu, H., Mei, Q., Xiong, C. and Zhao, J. (2014) Tumor-Suppressing Effects of miR141 in Human Osteosarcoma. Cell Biochemistry and Biophysics, 69, 319-325. https://doi.org/10.1007/s12013-013-9801-7

[34] Sandoval, J., Díaz-Lagares, A., Salgado, R., Servitje, O., Climent, F., Ortiz-Romero, P.L., Pérez-Ferriols, A., Garcia-Muret, M.P., Estrach, T., Garcia, M., Nonell, L., Esteller, M., Pujol, R.M., Espinet, B. and Gallardo, F. (2015) MicroRNA Expression Profiling and DNA Methylation Signature for Deregulated MicroRNA in Cutaneous T-Cell Lymphoma. Journal of Investigative Dermatology, 135, 1128-1137. https://doi.org/10.1038/jid.2014.487 


\section{Supplementary}

Table S1. Clinical characteristics of patient set 1.

\begin{tabular}{cccc}
\hline & Group 1 & Group 2 & Group 3 \\
\hline Gleason & G $>7$ & G $\leq 7$ & Non-cancer \\
Samples & $7(29.17 \%)$ & $8(33.33 \%)$ & $9(37.5 \%)$ \\
Age & & & 72 \\
Median & 67 & 70 & 72.25 \\
Mean & 69.43 & 70.25 & 8.62 \\
SD & 6.73 & $66-76$ & $62-83$ \\
Min - Max & $60-79$ & & \\
\hline
\end{tabular}

Table S2. Clinical characteristics of patient set 2 .

\begin{tabular}{cccc}
\hline & Group 1 & Group 2 & Group 3 \\
\hline Gleason & G $>7$ & G $\leq 7$ & Non-cancer \\
Samples & $14(22.58 \%)$ & $32(51.61 \%)$ & \\
Age & & & $68.81 \%)$ \\
Median & 65 & 68 & 68 \\
Mean & 67.25 & 66.94 & 6.87 \\
SD & 7.42 & $52-82$ & $62-76$ \\
Min - Max & $56-77$ &
\end{tabular}

Table S3. Primer of qRT-PCR.

\begin{tabular}{|c|c|c|c|c|}
\hline & RT primer & F primer & $\mathrm{R}$ primer & $\mathrm{Tm}$ \\
\hline $\mathrm{AR}$ & Oligo(dT) 18 & $5^{\prime}$-cctgctcaagacgcttctac- $3^{\prime}$ & $5^{\prime}$-ttccaatgcttcactgggtg-3' & 61.7 \\
\hline GAPDH & Oligo(dT) 18 & 5'-cggagtcaacggatttggtcgtat-3' & 5 '-agccttctccatggtggtgaagac-3' & 72.8 \\
\hline $\operatorname{miR}-141-3 p$ & 5 '-gtcgtatccagtgcagggtccgaggtattcgcactggatacgacccatct-3' & 5 '-cgagcgtgtaacactgtctggtaa-3' & 5 '-cagtgcagggtccgaggtatt- 3 ' & 68.2 \\
\hline U6 & $5^{\prime}$-cgcttcacgaatttgcgtgtca-3' & 5'-gcttcggcagcacatatactaaaat-3' & $5^{\prime}$-cgcttcacgaatttgcgtgtca-3' & 69.4 \\
\hline
\end{tabular}

Submit or recommend next manuscript to SCIRP and we will provide best service for you:

Accepting pre-submission inquiries through Email, Facebook, LinkedIn, Twitter, etc. A wide selection of journals (inclusive of 9 subjects, more than 200 journals)

Providing 24-hour high-quality service

User-friendly online submission system

Fair and swift peer-review system

Efficient typesetting and proofreading procedure

Display of the result of downloads and visits, as well as the number of cited articles

Maximum dissemination of your research work

Submit your manuscript at: http://papersubmission.scirp.org/

Or contact ijcm@scirp.org 